\title{
A digital learning tool based on models and simulators for food engineering
} (MESTRAL)

I. Suciu ${ }^{1}$, A. Ndiaye2 , C. Baudrit ${ }^{2}$, C. Fernandez ${ }^{2}$, A. Kondjoyan ${ }^{3}$, PS. Mirade ${ }^{3}$, J. Sicard ${ }^{3}$, P. Tournayre ${ }^{3}$, P. Bohuon ${ }^{4}$, P. Buche ${ }^{5}$, F. Courtois ${ }^{4}$, V. Guillard ${ }^{5}$, V. Athes ${ }^{6}$, D. Flick ${ }^{6}$, A. Plana-Fattori ${ }^{6}$, C. Trelea ${ }^{6}$, G. Trystram $^{6}$, G. Delaplace ${ }^{7}$, S. Curet ${ }^{8}$, D. Della Valle ${ }^{9}$, L. Pottier ${ }^{8}$, H. Chiron ${ }^{1}$, S. Guessasma ${ }^{1}$, K. Kansou ${ }^{1}$, M. Kristiawan ${ }^{1}$, G. Della Valle ${ }^{1}$

1 INRAE UR 1268, Biopolymers, Interactions \& Assemblies (BIA), 44316 Nantes, France

2 INRAE USC 1368, Institut de Mécanique et d'Ingénierie (I2M), CNRS, Université de Bordeaux, 33615 Pessac, France

3 INRAE UR 370, Qualité Produits Animaux (QuaPA), 63122 Saint-Genès-Champanelle, France 4 UMR-Qualisud, SupAgro, Universités de Montpellier, Avignon, La Réunion, CIRAD, 34398

Montpellier, France

5 Université de Montpellier, INRAE, UMR 1208, Ingenierie Agropolymères \& Technologies Emergentes (IATE), 34060 Montpellier, France

6 Université Paris-Saclay, INRAE, AgroParisTech, UMR 782 SayFood, 91300 Massy \& 78850 ThivervalGrignon, France.

7 INRAE, UMR 8207, Unité Matériaux et Transformations, Univ. Lille, CNRS, Centrale, 59000 Lille, France

8 ONIRIS, Université de Nantes, CNRS, GEPEA, UMR 6144, 44000 Nantes, France

9 Oniris, 44000 Nantes, France

Corresponding author: Guy.Della-Valle@inrae.fr

\begin{abstract}
This paper presents a digital learning tool, MESTRAL ( "Modélisation Et Simulation des TRansformations ALimentaires", "Modelling and Simulating Food Processing" in English), that can provide educators with a tool to teach food processing using simulators and a broad range of models derived from research in food science \& engineering. It was built using electronic knowledge books (eK-book). The eK-book represents knowledge in the form of concept maps and knowledge sheets, connected via a network of hypertext links. MESTRAL encompasses 15 modules, that cover approximately 150 hours of teaching and a broad range of real systems, from a single unit operation (e.g., frying a banana) to a logistic chain (e.g., ham cold chain). Each module conveys information on a food product or a food process, and includes a simulator based on a published scientific model. Altogether, the models address various scale of systems and are based on different theoretical
\end{abstract}


35 frameworks. For each simulator, the model inputs and outputs are stored in a database. Outputs are 36 visualized through abacuses, which can be used for virtual practice. MESTRAL modules also include 37 training exercises and tests to help students to assess the knowledge they have acquired during 38 consultation of the modules. Finally, MESTRAL has already been successfully tested by different 39 audiences according to various learning forms.

40

41 Keywords: abacus; concept map; electronic knowledge book; food processing; student 42 


\section{Introduction}

Despite an abundant scientific production, the use of models and simulators remains limited in the food industry where this approach is not familiar, in contrast with other technological sectors, and there is a clear lack of human resources to adopt modelling approaches in the food industry (Datta, 2016; Erdogdu et al., 2017; Djekic et al., 2019). Several educational institutions provide training in computerized techniques and approaches, including mechanistic approaches and multiscale modelling, in their food engineering curriculums, to face this issue.

Digital resources could contribute to these efforts by implementing simulators as educational tools in order to prepare future food engineers to use models (Datta, 2016). Among various initiatives in this sector, a short-term International School on Modelling and Simulation in Food and Bio Processes (http://www.virprofood.org/msfs2016/) was selected to be the training school of the Cost Action CA15118 FoodMC ${ }^{1}$. Run by the ISEKI ${ }^{2}$ Food Association, more than 100 scholars from all over the world have benefitted from it so far. Another well-known example dedicated to education in food engineering is the website created by Prof. Paul Singh, which contains video tutorials, lecture notes, animated films devoted to food processing equipment, virtual experiments, design problems for what-if analysis, and video lectures based on food science and engineering (Singh, 2008). Prof. Ashim Datta developed a "learning by doing" approach by introducing modelling and simulation approaches to solve biological problems, which can be implemented in a food context (Datta, 2015). In addition to these examples, scientific activity in food engineering generates a great deal of research products, such as large experimental databases, figures, texts, images and films obtained with a wide variety of instruments (from images of industrial equipment to microscopic images at molecular scale), models and simulators, decision-support systems. Most of them are available as downloadable documents or as web pages on the internet. Many professors individually use their own research products for teaching purposes. These individual actions could be combined on a collective scale to convert these research products, including models, into widely available digital resources.

A generic and collaborative approach would contribute to teach modelling in engineering, and facilitate its appropriation by the students (Carberry \& McKenna, 2014). Electronic knowledge books (eK-book) where knowledge is mainly represented by conceptual maps (Cmaps), might be used in this purpose. Indeed, they have been shown to be original and effective transfer tools (Ermine, 2010; Suciu et al., 2012), so they may be converted into digital learning tools. In turn, they could be shared by educational institutions and made available to a large audience. By providing Mathematical and Computer Science Methods for Food Science and Industry Integrating food

\footnotetext{
${ }^{1}$ Mathematical and Computer Science Methods for Food Science and Industry

${ }^{2}$ Integrating food Science and Engineering Knowledge Into the food chain
} 
Science and Engineering Knowledge Into the food chain online access, such tools would also offer good prospects for remote and self-training, and could be used for blended learning, such as in flipped classrooms (Datta et al., 2020).

Given this context, the aim of this article is to present a digital learning tool, to train people in food processing using models from academia. This tool, organized into a harmonized format using electronic knowledge books, is named MESTRAL ("Modélisation Et Simulation des TRansformations ALimentaires" that means in English "Modelling and Simulating Food Processing"). While familiarizing students with modelling approaches, MESTRAL would, at the same time, encourage their transfer to industry. For this purpose, we built 15 modules based on eK-book, which are described in the section 2 of this paper. We then implemented simulators based on models for different food processing applications. These models are detailed in section 3. Finally, after a first validation step involving all of the authors, we report some of the feedback of a survey taken on the first 100 users.

\section{Building the digital learning tool}

\subsection{Basic elements of the eK-book}

Knowledge transfer is defined here as the addition of transmission, assimilation and eventual use (Davenport \& Prusak, 1998). Knowledge can be collected and represented in various forms, like concept maps (Cmaps), in an electronic knowledge book (eK-book). To build the eK-book, we adapted the approach of Ermine (2010), initially designed for capturing know-how for the transfer of scientific knowledge following a methodology detailed by Suciu et al. (2014). An eK-book is a hypertext network (Conklin, 1987) in which knowledge is captured in a structured way using Cmaps, knowledge sheets and a glossary, connected by hypertext links. As a hypermediatool, it makes it possible to integrate videos, while allowing to download documents and browse web pages from the internet. As described in greater detail in Section 3, MESTRAL also includes simulators and training exercises.

The canonical concept map (Fig. 1a) is a hierarchical graph that describes a concept according to four types of ontological relationships: taxonomy (is-a), synonymy (is-synonym), mereology (hasas-parts) and domain relationship (is-characterized-by, is-measured-by, is-controlled-by, isimplemented-by, etc.). Taxonomy allows a concept to be positioned in a well-defined group (Brachman, 1983). Synonymy makes it possible to specify alternative concepts in a given knowledge domain. Mereology links an entity to its parts (Schulz et al., 2006) through relationships such as member-collection, matter-object, portion-mass, and phase-activity. Domain relationships make it possible to indicate how (with which methods) a concept (an operation, a product, a variable, etc.) is measured, observed, characterized or studied. The application of Cmap in MESTRAL is illustrated by 
the example taken from the module "Aroma release from yoghurt in mouth" (Fig. 1b). The specification of the main concept in a Cmap contains other concepts that are directly used to describe it, such as "strawberry flavour" in the example. This concept is then the main concept of another Cmap, as symbolized by icons giving access to this next Cmap, via a hyperlink. This way, the user can navigate within the network of Cmaps. As another example of application to MESTRAL, is the domain relationship "is characterized by" leading to the concept "viscosity" (of the yoghurt) (Fig. 1b).

A knowledge sheet is a document that captures less formal knowledge. It includes eight (8) fields: title, illustration, explanations, creation date, authors, keywords, see also and literature references. An example of a knowledge sheet is given for the "aroma release of yoghurt in mouth" module (Fig. 2). The illustration can be a video, a sound, a photo, a drawing, a graph, a table, an equation, etc., or a link to a document available online. Explanations are text that can be formatted (font, bold, italics, colour, etc.). Each author can be clicked on to access their contact details, including email address and the internet link to the web page of their home laboratory. Each keyword, contained in the glossary of the eK-book, can be clicked on to display its contextualized definition. The see also field contains the links to the related knowledge sheets that provide additional information. The literature references include those cited in the explanation field and other references that provide additional information. They are clickable to open a web page (that of the article on the publisher's website, for example) or to open a linked document.

All the documents in the eK-book and the hypertext links between them constitute a hypergraph opened on the internet. Thanks to the representation of knowledge, from a general Cmap to more specific maps, the user can browse the book until the desired detail level is reached. This knowledge structuring minimizes the disorientation and the cognitive load of the user and thus promotes the assimilation of knowledge (Amadieu et al., 2009). Disorientation is the property which assesses the difficulty of the user to locate himself and find information in the eK-book, whereas cognitive load measures the mental effort invested by the user to grasp the concept maps and to explore the eK-book.

\subsection{Application to MESTRAL}

The cornerstone of any MESTRAL module is the "model Cmap", which is an instance of the canonical map (Fig. 1a) specifying the model. It contains all the concepts and information on which the model relies. Hence, the model Cmap includes the type of model, its hypotheses, its input and output variables, its implementation, etc (Fig. 3).

As for any Cmap, more refined specifications of the concepts are available by clicking on the icons to open links towards other concept maps or knowledge sheets. The taxonomical relationship 
"type of model" especially refers to the theoretical framework in which the model is developed. A sheet, presenting in detail the equations that are solved, can also be opened from the output variables using the link "is-computed-by". In addition, the mereology relationship leads to the hypotheses under which these equations are solved (e.g., the influence of gravity is discarded), and this box also refers to the assumptions that are made (e.g., the flow is steady at the entrance of the tubular heat exchanger). Finally, domain relationships refer to the input/output variables of the model. For example, inputs may be the physical properties of the foods, the equipment geometry or the process settings. All these concepts may lead to more detailed concepts or knowledge sheets available by browsing. Outputs also include icons that, once clicked on, open graph sheets where the variables are represented as functions of input variables (e.g., time -temperature graphs) for selected values of other inputs. The detailed method of results presentation, i.e., post-processing, is described in detail in Section 3.3.

To complete the eK-book, every MESTRAL module is provided with a glossary where all of the keywords are listed and defined, and variable units recalled. Input and output variables generally belong to the keywords list. Their definition appears when browsing the keywords in the text of a knowledge sheet. In addition, the user looking for a specific keyword can request the list of documents (Cmap, knowledge sheet) where this keyword appears.

At the end of the eK-book, training exercises are proposed with three different levels of difficulty, beginning with the easiest, which implies knowledge of most basic concepts and of keyword definition. Conversely, the most difficult ones not only require the acquisition of the knowledge conveyed by the maps and sheets, but the use of the simulator as well. Simulators are described in another section. They allow the student to experiment with a "learning by doing" approach, i.e., virtual practice.

At the beginning of every module, six motivating questions are proposed to the student. For every question, a learning path, or itinerary, has been defined to indicate how to navigate within the module so as to collect the information required to answer the initial question. These itineraries make sure that most of the documents can be covered by the student, and they decrease the risk of disorientation.

The eK-book makes it possible to build modules with a common structure, regardless of the systems studied (food and process), through models that are presented in the next section together with the simulators implemented. 
Many valuable studies have been dedicated to food process modelling and the purpose of this section is to locate the various approaches used in MESTRAL in the modelling frameworks. Several reviews have underlined the various potentialities and challenges of modelling and simulation in food processing (Trystram, 2012; Manlik \& Borkar, 2015; Datta, 2016; Saguy, 2016; Erdogdu et al., 2018; Vitrac \& Touffet, 2019). Scientific work in food process engineering has led to models that use different mathematical formalisms, which can predict the composition (\% water, micronutrients, neo-formed compounds, etc.) and properties (technological, sensory, safety, etc.) of a product according to its initial composition and the process operating conditions.

Computational modelling was developed in food processing, in particular, by applying Computational Fluid Dynamics and using specialized software (Datta, 2016). This approach, also referred to as mechanistic, is physics-based and mostly relies on the theoretical framework of continuum mechanics and thermodynamics. It may appear complex due to mathematical formalism, and requires considerable investment, first, to analyse the problem and, then, to make the properties of the food system available. In a complementary manner, experimental approaches may be guided by statistical models that require the fitting of experimental data according to numerical procedures and reasoning. This modelling approach can lead to the optimization of a product or a process in a shorter time, but with lack of flexibility since it is valid in a narrower domain; such models are data-driven models and include a part of empiricism (Sablani et al., 2007). Note that the degree of empiricism may be reduced when the model integrates professional know-how with scientific knowledge, leading to phenomenological models. By doing so, the understanding of the mechanisms governing the studied phenomena is improved, as illustrated by the basic knowledge models proposed for the breadmaking chain (Della Valle et al., 2014). Recent approaches at the crossroads of mathematics and artificial intelligence provide adapted methods to deal with heterogeneous sources of knowledge and with different mathematical formalisms used by different disciplines that are manipulated under different forms of uncertainty (natural randomness, imprecision, data scarcity, vagueness, etc.) (Filter et al., 2015). All these approaches - from mechanistic to data-driven - represent, in various mathematical forms, the relationships between input and output variables. They are used in different MESTRAL modules and make it possible to simulate the food process system in a realistic domain.

\subsection{MESTRAL models}

In the following, an overview of the models implemented in MESTRAL is presented, roughly ordered from a fine to a coarse knowledge grain, and from small to large scales of the system studied (Fig. 4). The knowledge grain is defined here according to the level of uncertainty of the knowledge gained by the model results: the larger the uncertainty level, the coarser the grain. The largest 
systems are at the bottom right and represent a food chain, addressed using the simplest theoretical

217 framework. As we move along the horizontal axis, the knowledge grain becomes coarser and the 218 model predictions become more uncertain, resulting in general trends rather than accurate 219 predictions. In Fig. 4, the overall trend suggests that MESTRAL models arrange around the bisector. However, it is noteworthy that food engineering models may lead to acceptable precision (i.e. a fine knowledge grain) at a large scale, by computing properties from knowledge about structure at a lower scale, which is precisely the challenge addressed by multi-scale modelling (Ho et al., 2013). As seen for the complementary information reported in Table 1, these models rely on different theoretical frameworks, from continuum mechanics (physics-based models) to stochastic approaches and statistical analysis (data-driven models). They are implemented through various numerical and computer resources, either based on commercial software, possibly using Finite Elements (FE), or developed by the scientists themselves. For the purpose of simplicity, the literature references that have led to the development and validation of every model are not mentioned all, but the most recent ones are quoted so that the reader may, in turn, find more in-depth information when needed.

Deep fat frying of starch foods involves coupled heat and mass (water and oil) internal transfers. By solving the partial differential equations (PDE) of these transfers in thin or thick slices of plantain banana, the 2D numerical, FE-based model makes it possible to predict the nutritional impact through various indicators (nutrient density and toxic components such as acrylamide) that are linked to computed fields such as temperature, moisture and oil content (Bassama et al., 2015). Using the same formulation and numerical resources to solve heat mass transfer PDEs, a deterministic approach is proposed to predict the transformation of starch suspensions in a tubular heat exchanger by computing the fields of velocity, pressure and temperature along the tube. In this case, an essential original feature comes from the two-way coupling of rheology, fluid flow and heat transfer, taken into account by the kinetics of starch granule swelling, which depends on temperature and drastically modifies the apparent viscosity (Plana-Fattori et al., 2016).

Based on the solution of the mass balance equations in three compartments (nose/pharynx/food layer), the model of in vivo aroma release computes the evolution of the concentrations of representative aroma compounds (diacetyl and ethyl octanoate). The evolution of concentrations is computed in the product and in the air after swallowing for yoghurts with various fat contents (Trelea et al., 2008). Because it integrates the consumer's physiology and because aroma release is correlated with sensory perception, this model is used to address the re-engineering of food formulations.

Solid food texture is addressed by a 3D numerical, FE-based mechanical model that considers cereal food as a solid foam in the linear elastic domain. Compression loading of virtual realistic 
cellular structures is simulated and the model computes the variations of foam stiffness, represented by the mechanical property of Young's modulus with respect to the foam density. The correlation between foam density and stiffness is compared to the analytical solution from Gibson-Ashby's model, and with experimental data obtained on bread, biscuits and breakfast cereals (Guessasma et al., 2008).

Non-conventional heating is treated through a simplified 1D numerical Finite Volume model that accounts for microwave-matter interactions in the case of unidirectional propagation (plane wave) (Curet et al., 2009). The model provides a tool for predicting temperature kinetics during a microwave heat treatment, as well as the absorbed power density as a function of the depth for two foods - bread and meat - to deal with two different moisture levels.

The modelling of dairy food foaming considers the 1D-flow of viscous fluid in a static mixer $\left(\mathrm{SMX} \mathrm{X}^{\mathrm{TM}}\right)$ and its expansion tube, where the pressure drop is computed at various steps (Laporte et al., 2014). Hence, along the tube, it is possible to calculate the incorporated air fraction and size of the bubbles and the power consumption from geometry data, gas and liquid flow rates, as well as the rheological properties of the dairy formulation.

The flow of molten starchy products in a twin screw extruder is modelled in the same way by summing the pressure drop or rise in each screw part (Della Valle et al., 1993). This analytically solved, 1D model makes it possible to compute the main flow variables, melt temperature, pressure, shear rate and viscosity, and the specific mechanical energy along the screws. The model is implemented in a commercial software program called Ludovic ${ }^{\circ}$, that is used to perform simulations. Expansion of the starch melt at the die outlet to generate airy snack foods has also been tackled by a phenomenological model that predicts cellular structure (Kristiawan et al., 2019).

The model of food packaging is based on ordinary differential equations (ODEs) that describe mass transfer phenomena in the system defined by the food and the packaging material (Guillard et al., 2012). By coupling these ODEs with the gas consumption of microbial species, it makes it possible to predict product shelf life (Chaix et al., 2015). It also includes a multi-criteria decision support system that helps the user to choose a package for a given food. The multi-criteria choice is then adapted to the different actors in the food packaging sector (Guillard et al., 2015).

The model of the hot air-drying process of agricultural products (corn and rice grains) is based on the concept of drying kinetics, which explicitly considers the heat and mass transfers between three compartments: the surrounding air, and the external layer and the core of the grain (Abud Archila et al., 2000). In addition to time-temperature and moisture variations, the model also predicts the impact of drying on grain quality using an image bank.

Similar phenomena of heat and matter transfer applied to the cooling of carcasses can be modelled using a 1D numerical approach (Kondjoyan \& Daudin, 1997) that makes it possible to 
calculate the kinetics of temperature at different points (surface, core, average) of the carcass for two animal sizes (typically pork and rabbit). The evolution of weight loss of the carcass is also predicted, keeping in mind that this loss must be minimized for quality purposes.

Still considering fresh animal proteins (white fish and beef), an application of the highpressure (HP) treatment process (up to $500 \mathrm{MPa}$ ) is addressed through the use of experimental results (Cheret et al., 2005). In this case, the phenomenological model makes it possible to study the increase in the shelf life of these products thanks to this HP process, and its parameters (time, pressure level), while taking the organoleptic changes (texture and colour) observed after treatment into account.

The mixing process in a stirred tank is addressed by modelling principles that use dimensional analysis, with applications to the homogenization of sucrose solutions, the dissolution of dairy powders and heat transfer within viscous solutions of glucose syrup. It is then possible to predict the mixing time and the power demand of the equipment, the dissolving time and the heat transfer coefficient using abacuses of dimensionless numbers (Reynolds, Nusselt and power numbers), established from the analysis of the mixing operation and from dedicated experiments (Delaplace et al., 2015). In this case, the interest of using dimensionless numbers to reason about scaling up using a physics-based approach is shown.

The mixing process is also a critical operation in the bread-making chain since it converts a solid divided medium, the flour, into a continuous viscoelastic one, the dough. In this case, mixing modelling is addressed through an expert system known as AsCoPain ${ }^{\circledR}$, which models the bread technologists' expertise using a qualitative algebra (Ndiaye et al., 2009). This model makes it possible to calculate the sensory variables that define the state of the bread dough on the basis of the formulation variables (characteristics of the flour) and the operating conditions of the mixer (Kansou et al., 2014). This module also includes a simple phenomenological model of the dough-proofing stage, directly affected by parameters of the mixing process (Kansou et al., 2013).

Heterogeneous knowledge can also be assembled in a model using Dynamic Bayesian Networks (DBN) in order to predict the ripening process of Camembert-type cheese (Baudrit et al., 2010). While also introducing conditional probabilities, the model maps the evolution of the organoleptic properties of cheese according to microbial activity, which itself depends on its environment. The model helps to reduce the uncertainties linked to the working, the design and the control of the ripening process.

Conditional probabilities are also used for predictive microbiology, which is coupled to a simple heat transfer model of three compartments of the cold chain. This model describes the evolution of the temperature and of the microbial load of ham slices (Flick et al., 2012). Taking several random variables into account (residence time in the different compartments, adjustment of 
the thermostat of the refrigerator, speed of growth of micro-organisms), the model makes it possible to represent the influence of equipment and consumer behaviour on the health safety aspects of the ham slices.

As may be seen from this rapid review, these models address a large panel of real (food and process) systems, at various scales and through different theoretical frameworks (Fig. 4). Actual access to MESTRAL on the computer screen is given by the portal presenting the fifteen (15) modules, each one illustrated by an image of the system, according to following link http://thot.i2m.u-bordeaux.fr/mestral/portail/. Each model is assigned a model Cmap (see Section 2.2) and a simulator that is embedded in the modules as described below.

\subsection{Post-processing and simulators}

Implementing MESTRAL models raises two issues: first, the access to commercial modelling software; and, second, the necessity of having sufficient computation resources to run the simulation. Both are of course prohibitive for a potentially intense use of the simulators by the students, exacerbated by remote access from home and the use of their own terminals (smartphone, tablet or PC). Therefore, a database was included in each module by collecting the results of output variables (values computed by the model) for a selected number of values of input variables. This database is run using abacuses, a technique traditionally used for learning purposes, as suggested by Lopez et al. (2018) for mechanical material engineering. Clearly, the representation of abacuses is limited by the large number of variables and of the values that these variables can take. In MESTRAL, no more than four to five abacuses, one per output variable, with four to five curves, are presented on the same screen page (Fig. 5a, b). Sliders make it possible to select discrete values (up to ten values) of the input variables. For every combination of sliders positions, a set of graphs is instantaneously presented. In Fig. 5a, graphs represent, for example, the grain water content after various drying times and for different drying conditions. In Fig. 5b, the graphs represent the variations of starchy product temperature, pressure, viscosity at the extruder die outlet, and specific mechanical energy for various screw speed, feed rate and barrel temperature values.

The simulator includes the abacuses drawn from the database and the graphical representation of the results. All simulator interfaces are developed in HTML5, CSS3 and Javascript. These are the core technologies for building web pages, which allows the simulators to be easily accessible in the future. Hence, the generation of abacuses is automated and their presentation is adapted to the student using digital charts that allow storage and post-processing of highly variable solutions in a very efficient way (Lopez et al., 2018). Note that it allows any user to perform a simulation of the process without fully understanding the theoretical framework of the model, but with knowledge of its basic principles. Conversely, it can incite the student to become acquainted 
with this framework as well as with the equations on which it is based, since this ease-of-use can be compared to the possibility of "driving a car without knowing how its engine works".

\section{First tests and surveys for validation}

The validation of the work involved two testing steps corresponding to two different audiences and questionnaires.

In the first one, performed during a two-day seminar, the twenty-five (25) contributors first checked the consistency, the completeness and the accuracy of the content of their module. They also acted as "beta-testers" by browsing two to three other modules for 2 to 4 hours each. To do this, they had to fill in an open questionnaire (see Appendix A), and declare whether they considered themselves as expert or novice in the field covered by the module. Those who have already worked and published in the area are referred to as experts, whereas those who have never read any scientific article on the topic are considered as novice. The answers were collated and transmitted to each of the contributors who then performed the appropriate corrections.

In a second step, MESTRAL was tested by a large audience (100 users) from various horizons, students and professionals, and with various education levels in engineering and science (chemical, agricultural), from bachelor's degrees to PhDs, on a volunteer and anonymous basis. It took place during the period from September 2018 to April 2019. No specific instruction was given and testers could choose any module on the website "http://thot.i2m.u-bordeaux.fr/mestral/portail/" using appropriate identifier and password. So MESTRAL was mainly tested for self-learning, possibly leading to a flipped classroom. Conversely, in some cases, blended learning conditions were also proposed. In this case, the students were asked to use a module in the presence of the teacher, who was the module's contributor. After each test, the user was asked to fill in a questionnaire (see Appendix B) of twenty (20) questions. The results reported in Fig. 6 show that: (a) more than $90 \%$ of the testers were (quite) satisfied overall and (b) found the content clear and relevant; (c) the learning effort was judged moderate and equally distributed from significant to very low; whereas (d) about $75 \%$ found browsing on the eK-book quite easy. Finally, a large majority found it easier to learn about the models by running the simulators than by a traditional presentation of the model equations and of the theoretical framework (Fig. 6e).

However, this positive trend should be balanced by the necessity to test the students for the acquired knowledge, a purpose for which learning tests (quizzes) have also been planned and implemented. The aim of this survey was clearly not to obtain definitive answers, but just to obtain initial feedback about the way the knowledge, and especially the models, are presented in the eKbook. Altogether, the 15 MESTRAL modules integrated in the eK-book contain over six hundred (600) 
Cmaps and more than seven hundred (700) knowledge sheets, which leads to an overall total of approximately $150 \mathrm{~h}$ of teaching, including student's effort. A more systematic evaluation by a larger group of students is to be scheduled under well-defined learning conditions. From the feedback, the necessary improvements will be performed prior to delivering this digital resource to educational institutions. Up until now, all of the modules were written in French, and one has been translated into English (Aroma release from yoghurt in mouth), which suggests that translation into another language is within reach, provided the necessary resources are available. Presently, free access to MESTRAL may be granted upon personal request to the corresponding author of this paper.

\section{Conclusion}

In this paper, we have presented an original digital learning tool known as MESTRAL. It was built for the purpose of teaching food processing using models and that covers approximately $150 \mathrm{~h}$ of teaching, including student's effort. It is based on knowledge engineering methods such as concept maps, which have been adapted for this purpose, and are implemented in an electronic knowledge book. Fifteen (15) models, all derived from research studies, are treated. They cover a wide range of real applications and can be mapped according to the system scale and the knowledge grain assessed by the different theoretical frameworks under which they are developed. This variety may clearly be a source of complexity for the student. However, cognitive load and disorientation can be reduced as a result of the harmonized knowledge representation. Furthermore, using the abacus technique, the results of simulations integrated into a database are graphically represented. Hence, the user can simulate various operations of the modelled system and test the influence of changes of either process conditions or product formulation on final food properties and process performances. Finally, an initial validation test on a large audience made it possible to obtain encouraging feedback. As advocated by the basic hypothesis of this work, this result suggests that by letting students simulate the workings of the (food and process) system, such a tool may contribute to sensitizing them about modelling approaches and various theoretical frameworks. Furthermore, since the results are derived from recent scientific research studies, they may draw the student's attention to innovative processes. As a digital learning tool, MESTRAL could provide students with remote and self-training resources, and could also be used for blended learning by educational institutions. Finally, because of its potential to share digital resources, it contributes to a collaborative response to the teaching of modelling and favours the transfer of computer-aided engineering to the food industry.

\section{Acknowledgements:}


This work was developed within the framework of the AgreenCamp project (Agrosciences for Digital Training), which was supported by the grant ANR-15-IDFN-0001-01. The authors are grateful to Philippe Prevost (Agreenium), the AgreenCamp coordinator, for his fruitful advice, and to Catherine Herry (INRAE, HR) for her support during the consolidation stage, as well as to all of the Agreenium team members for their invaluable help.

\section{References}

Abud-Archila, M., Courtois, F., Bonazzi, C., Bimbenet, J.J., 2000. Processing quality of rough rice during drying - modelling of head rice yield versus moisture gradients and kernel temperature. J. Food Eng. 45, 161-169.

Amadieu, F., van Gog, T., Paas, F., Tricot, A., Mariné, C., 2009. Effects of prior knowledge and concept-map structure on disorientation, cognitive load, and learning. Learning and Instruction, 19, 376-386.

Bassama J., Achir N., Trystram G., Collignan A., Bohuon P., 2015. Deep-fat frying process induces nutritional composition diversity of fried products assessed by SAIN/LIM scores. J. Food Eng., 149, 204-213.

Baudrit, C., Sicard, M., Wuillemin, P.H., Perrot, N., 2010. Towards a global modelling of the Camembert-type cheese ripening process by coupling heterogeneous knowledge with dynamic Bayesian networks. J. Food Eng. 98, 283-293

Brachman, R.J., 1983. What IS-A is and isn't: an analysis of taxonomic links in semantic networks. Computer, 16, 30-36.

Carberry, A.R., McKenna, A.F., 2014. Exploring student conceptions of modeling and modeling uses in engineering design. J. Eng. Education, 103,77-91.

Chaix, E., Broyart, B., Couvert, O., Guillaume, C., Gontard, N., Guillard, V., 2015. Mechanistic model coupling gas exchange dynamics and Listeria Monocytogenes growth in Modified Atmopshere Packaging of non-respiring food. Food Microbiol. 51, 192-205

Chéret, R., Chapleau, N., Delbarre-Ladrat, C., Verrez-Bagnis, V., and de Lamballerie, M., 2005. Effects of high pressure on texture and microstructure of sea bass (Dicentrarchus labrax L.) fillets. J. Food Sci. 70, 477-483

Conklin, J., 1987. Hypertext: an introduction and survey. Computer, 20, 17-41

Curet, S., Rouaud, O., Boillereaux, L., 2009. Effect of sample size on microwave power absorption within dielectric materials: 2D numerical results vs. closed-form expressions. AIChE Journal, 55(6), 1569-1583 
Datta, A.K., 2015. Computer-aided Engineering: Applications to Biomedical Processes. https://courses.cit.cornell.edu/bee4530

Datta, A.K., 2016. Toward computer-aided food engineering: Mechanistic frameworks for evolution of product, quality and safety during processing. J. Food Eng. 176, 9-27

Datta, A. K., Ukidwe, M. S., Way, D. G. 2020. Simulation-Based Enhancement of Learning: The Case of Food Safety. Journal of Food Science Education, 19, 192-211

Davenport, T., Prusak, L. 1998. Working knowledge: how organisation manage what they know. Harvard Business School Press, Boston (MA), 224p

Delaplace, G., Loubière, K., Ducept, F., Jeantet, R., 2015. Dimensional analysis for modeling processes in food processes. ISTE Press, Elsevier, 356p

Della Valle, G., Barrès, C., Plewa, J., Tayeb, J., Vergnes, B., 1993. Computer simulation of starchy products transformation by twin screw extrusion. J. Food Eng., 19: 1-31.

Della Valle, G., Chiron, H., Cicerelli, L., Kansou, K., Katin,a K., Ndiaye, A., Whitworth, M. \& Poutanen, K. 2014. Basic knowledge models for the design of bread texture. Trends Food Sci. Technol. 36, $5-14$

Djekic, I., Mujčinović, A., Nikolić, A., Režek Jambrak, A., Papademas, P., Hailu Feyissa, A., et al., 2019. Cross-European initial survey on the use of mathematical models in food industry. J. Food Eng. $261,109-116$.

Erdogdu F, Sarghini F, Marra F., 2017. Mathematical modeling for virtualization in food processing. Food Eng. Rev. 9, 295- 313.

Erdogdu, F., Karatas, O., Sarghini, F., 2018. A short update on heat and mass transfer modelling for computational food processing in conventional and innovative processing. Cur. Opinion Food Sci. 23, 113-119

Ermine, J.-L., 2010. Methods and tools for Knowledge Management in research centres. Electronic journal of knowledge management 8, 293-306.

Filter, M., Appel, B., \& Buschulte, A., 2015. Expert systems for food safety. Current Opinion in Food Science, 6, 61-65

Flick, D., Hoang, M.H., Alvarez, G., Laguerre O., 2012. Combined deterministic and stochastic approaches for modelling the evolution of food products along the cold chain. Part I: Methodology, International Journal of Refrigeration, 35, 907-914

Guessasma, S., Babin, P., Della Valle, G., Dendievel, R., 2008. Relating cellular structure of open solid food foams to their Young's modulus: finite element calculation. Int. J. Solids Struct., 45, 2008, 2881-2896

Guillard, V., Guillaume, C., Destercke, S., 2012. Parameter uncertainties and error propagation in modified atmosphere packaging modelling. Postharvest Biol. Technol. 67, 154-166. 
Guillard, V., Buche, P., Destercke, S., Menut, L., Guillaume, C., Gontard, N., 2015. A Decision Support System for designing biodegradable packaging for fresh produce. Computers and Electronics in Agriculture 111, 131-139

Ho, Q.T., Carmeliet, J., Datta, A.K., Defraeye, T., Delele, M.A., Herremans, E., Opara, L., Ramon, H., Tijskens, E., van der Sman, R., Van Liedekerke, P., Verboven, P., Nicolaï, B.M., 2013. Multiscale modeling in food engineering. J. Food Eng. 114, 279-291.

ISEKI, International School on Modelling and Simulation in Food and Bio Processes http://www.virprofood.org/msfs2016/

Kansou, K., Chiron, H., Della Valle, G., Ndiaye, A., Roussel, P., Shehzad, A. (2013). Modelling wheat flour dough proofing behaviour: effects of mixing conditions on porosity and stability. Food and Bioprocess Technology, 6, 2150-2164.

Kansou, K., Chiron, H., Della Valle, G., Ndiaye, A., Roussel, A., 2014. Predicting the quality of wheat flour dough after mixing by modelling expert's know-how. Food Res. Int, 64,772-782, 2014

Kondjoyan, A., Daudin, J.D., 1997. Optimization of airflow conditions during chilling and storage of carcasses and meat products J. Food Eng., 34, 243-258.

Kristiawan, M., Della Valle, G., Kansou, K., Ndiaye, A., Vergnes, B., 2019. Validation and use for product optimization of a phenomenological model of starch foods expansion by extrusion. J. Food Eng., 246, 160-178

Laporte, M., Loisel, C., Della Valle, D., Riaublanc, A. and Montillet, A., 2014. Flow process conditions to control the void fraction of food foams in static mixers . J. Food Eng., 128, pp. 119-126.

Lopez, E., Gonzalez, D., Aguado, J.V., Abisset-Chavanne, E., Cueto, E., Binetruy C., Chinesta, F. 2018. A Manifold Learning Approach for Integrated Computational Materials Engineering. Archives of Computational Methods in Engineering, 25, 59-68

Manlik, AD., Borkar, BR., 2015. Simulation in Food Processing - A Review. International Journal of Enhanced Research in Science Technology \& Engineering, 4, 151-155

Ndiaye, A., Della Valle, G., Roussel, P., 2009. Qualitative modelling of a multi-step process: the case of French breadmaking. Expert Syst. with Appli., 39, 1020-1038

Plana-Fattori A., Flick D., Ducept F., Doursat C., Michon C., Mezdour S. (2016) A deterministic approach for predicting the transformation of starch suspension in tubular heat exchangers. J. Food Eng.,171, 28-36.

Raboutet, C., Fernandez,C., Le Blanc,B., Della Valle, G.,' Ndiaye, A., 2008. A knowledge base on cereal food foams processing and behaviour. In "Bubbles in Food 2", Eds G.M. Campbell, M.G. Scanlon \& D.L. Pyle. Eagan Press, St Paul, MN, USA, 381-388.

Sablani, SS., Datta, AK., Rahman, MS., Mujumdar, AS., 2007. Handbook of Food and bioprocess modelling techniques. CRC Press, Taylor \& Francis, Boca Raton, FL, USA, 605p 
Singh, R.P., 2008. Immersive Learning Platforms development of Educational Simulations Based on Food Processing. Project details available at: http://cris. nifa.usda.gov/ and http://www.rpaulsingh.com/learning.html

Schulz, S., Kumar, A., Bittner, T., 2006. Biomedical ontologies: what Part-Of is and isn't. J. Biomedical Informatics, 39, 350-361.

Suciu, I., Fernandez, C., Le Blanc, B., Raboutet, C., Ndiaye, A., 2012. How to Acquire Scientific Knowledge for University to Industry Knowledge Transfer. Proc. Fourth International Conference on Information Process and Knowledge Management, Valencia, Spain, Jan $30^{\text {rd }}$ Feb. $4^{\text {th }}$, eKNOW 2012, 24-27.

Suciu, I., Jmal, A., Le Blanc, B., Irle, M., Michaud, F., Fernandez, C., Raboutet, C., Ndiaye, A., 2014. Acquisition, representation and transfer of scientific knowledge via a knowledge book. Proc. 1er Colloque International Connaissances et Informations en Action, Bordeaux, France, May $22^{\text {nd }}-23^{\text {rd }}, \mathrm{ClA}^{\prime} 2014: 5-14$

Trelea I.C., Atlan S., Déléris I., Saint-Eve A., Marin M., Souchon I. (2008). Mechanistic mathematical model for in vivo aroma release during eating of semi-liquid foods. Chemical senses, 33(2), 181-192

Trystram, G., 2012. Modelling of food and food processes. J. Food Eng. 110, 269-277

Vitrac, O., Touffet, M., 2019. Food Process Modeling. In: Ferranti, P., Berry, E.M., Anderson, J.R. (Eds.), Encyclopedia of Food Security and Sustainability, Elsevier, 1, 434-454. 
Figure 1: The canonical concept map (a) and an example of an application taken from the module "Aroma release from yoghurt in mouth" (b). Concepts are written in the boxes. They are linked by relationships from left to right: taxonomy (pink), synonymy (grey), mereology (blue) and domain (green). In the example, there is no synonymy relationship. Only the taxonomic relationship is always present on all the instances of the canonical concept map. Small icons that appear in Cmap (b) give access to another Cmap or to a knowledge sheet that can be opened by clicking on it.

Figure 2: Example of a knowledge sheet taken from the module "Aroma release from yoghurt in mouth" with the eight fields, from top to bottom: title, illustration, explanations, creation date, authors, keywords, see also and literature references.

Figure 3: Concept map adapted to the representation of the model, taking the model of "Heat exchanger for starch suspension", for example. Note that a concept "simulator" is added on the right to represent how the model is implemented and to give access to the results computed by the model. A knowledge sheet may be opened from this Cmap using the icons, providing information about the theoretical framework on which the model is based.

Figure 4: Schematic mapping of the various models implemented in MESTRAL according to their knowledge grain (from more to less accurate predictions, $x$ axis) and size scale of the modelled system (y axis). Models dealing with multiphase transport of heat and mass in (semi) solid medium are coded in red, whereas blue ones refer more to models that address the flow of complex media, with momentum transfer and large deformations, i.e., where rheology is pivotal. Purple codes stand for models involving both.

Figure 5: Two screenshots of the MESTRAL simulator for "rice grain drying" (a) and "extrusioncooking of cereals" (b). On the upper part, sliders (green) feature the numerical values of model input variables. Below, several abacuses present the simulation results for the above input combinations and for various model parameters (initial and drying conditions in the case of grain drying (a); extruder operating conditions in the case of extrusion (b). Note that for real use, the graphs may be enlarged at the user's demand.

Figure 6: Overview of the results of the second validation step, i.e., testing MESTRAL on a large audience (100 students) on the basis of a questionnaire (Appendix B): (a) overall satisfaction 
585 (question \#9); (b) relevance and clarity of the knowledge conveyed; (c) mental effort made (cognitive 586 load, \#12); (d) navigating smoothness (\#14); and (e) comparison to conventional lesson (\#17).

587

588

589 
(a)

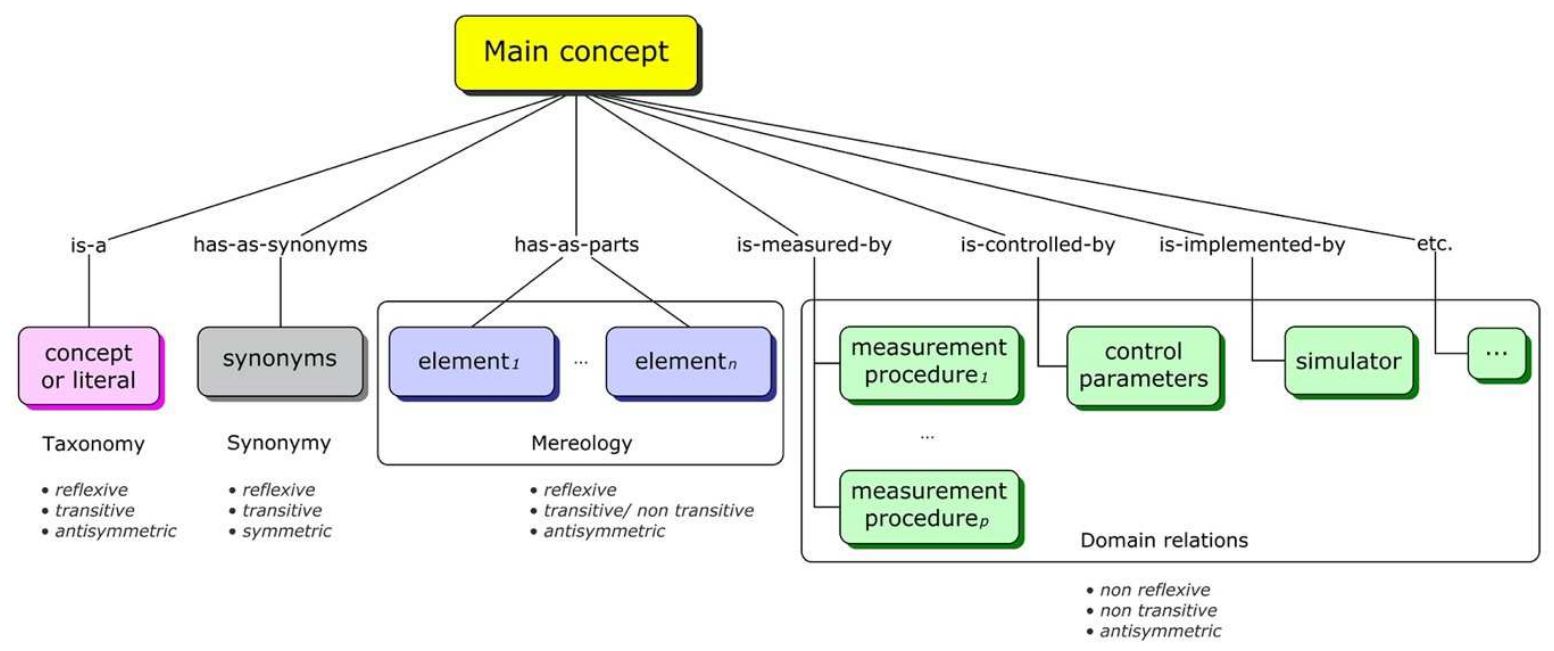

(b)

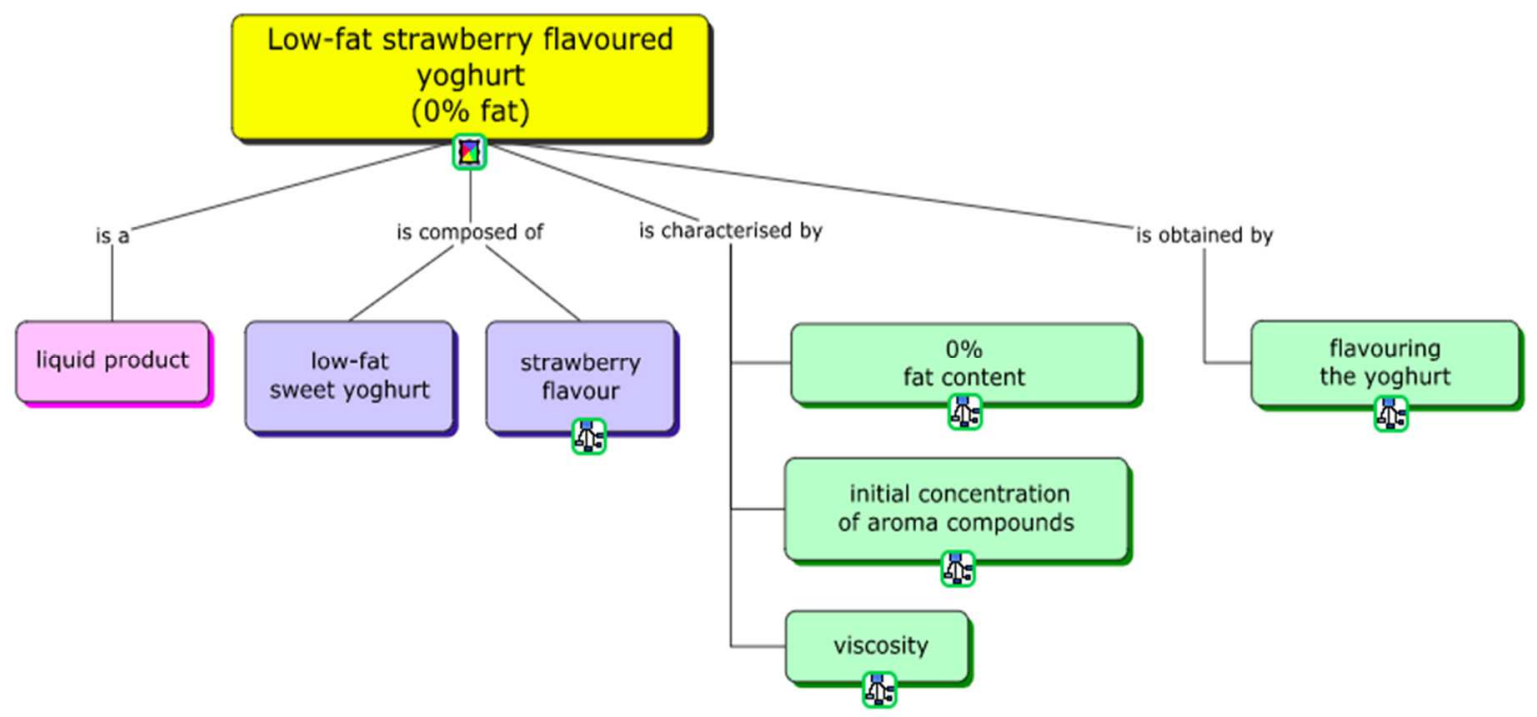

MESTRAL

Fig.1 


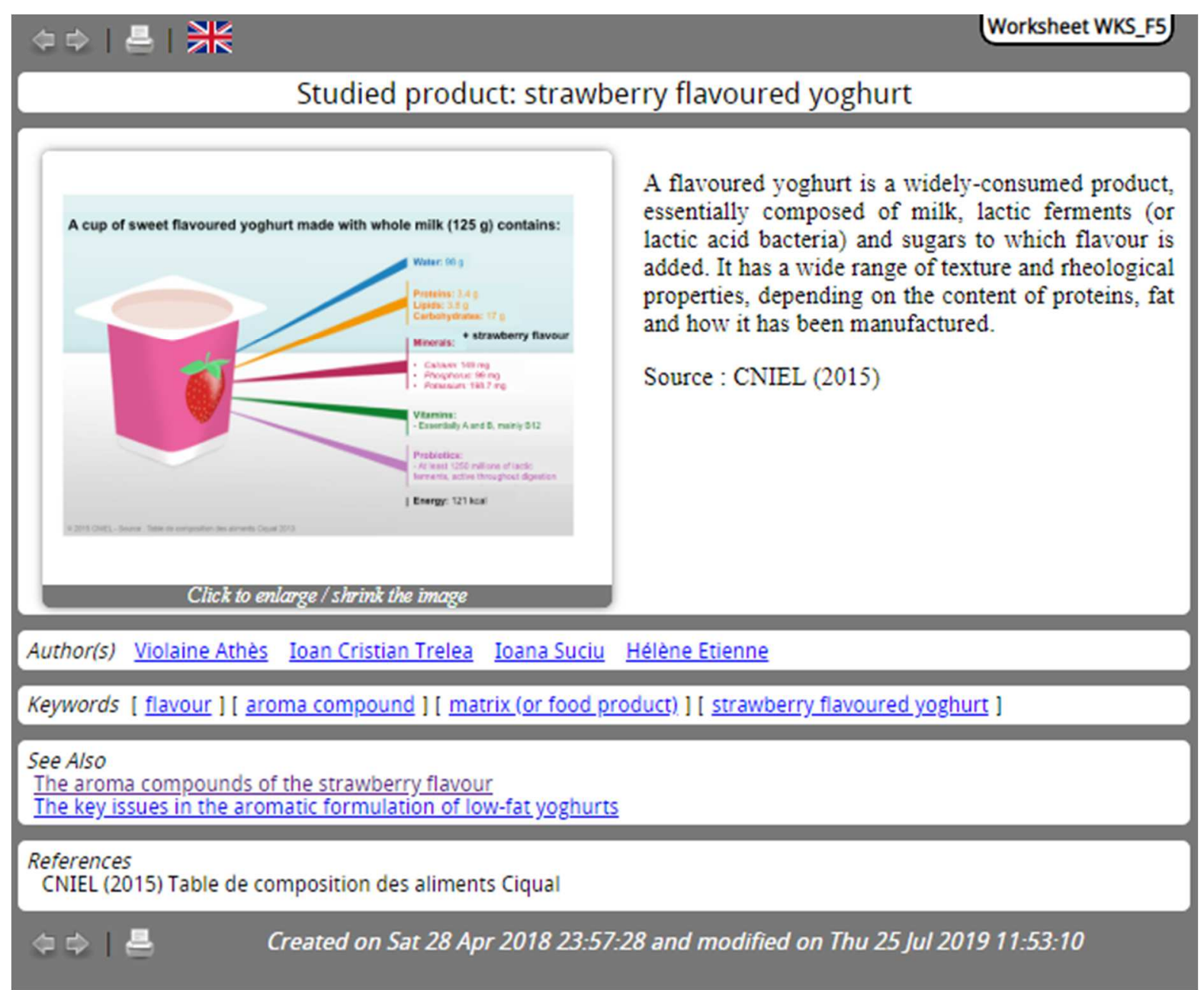

MESTRAL

Fig.2 


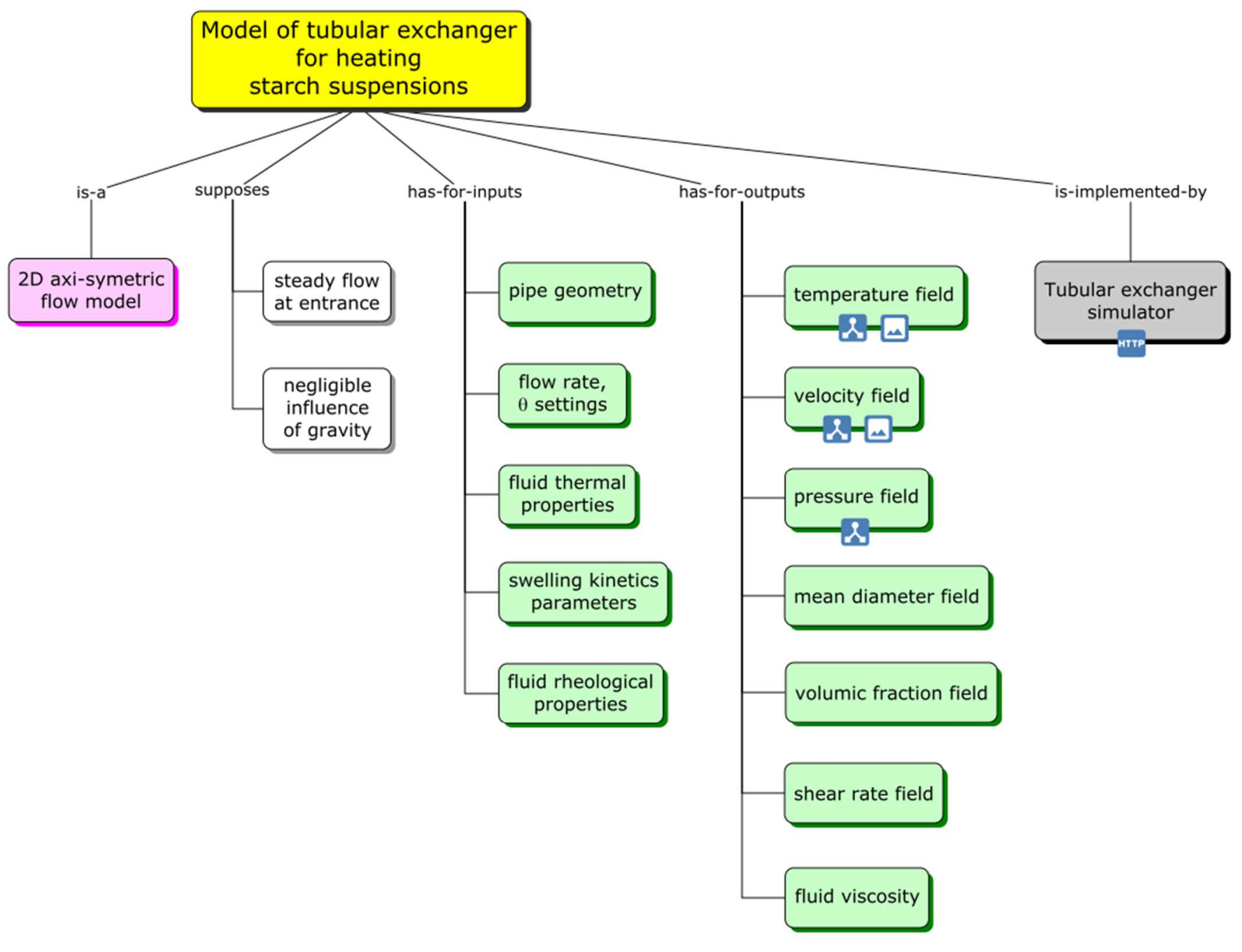

Mestral

Fig.3. 


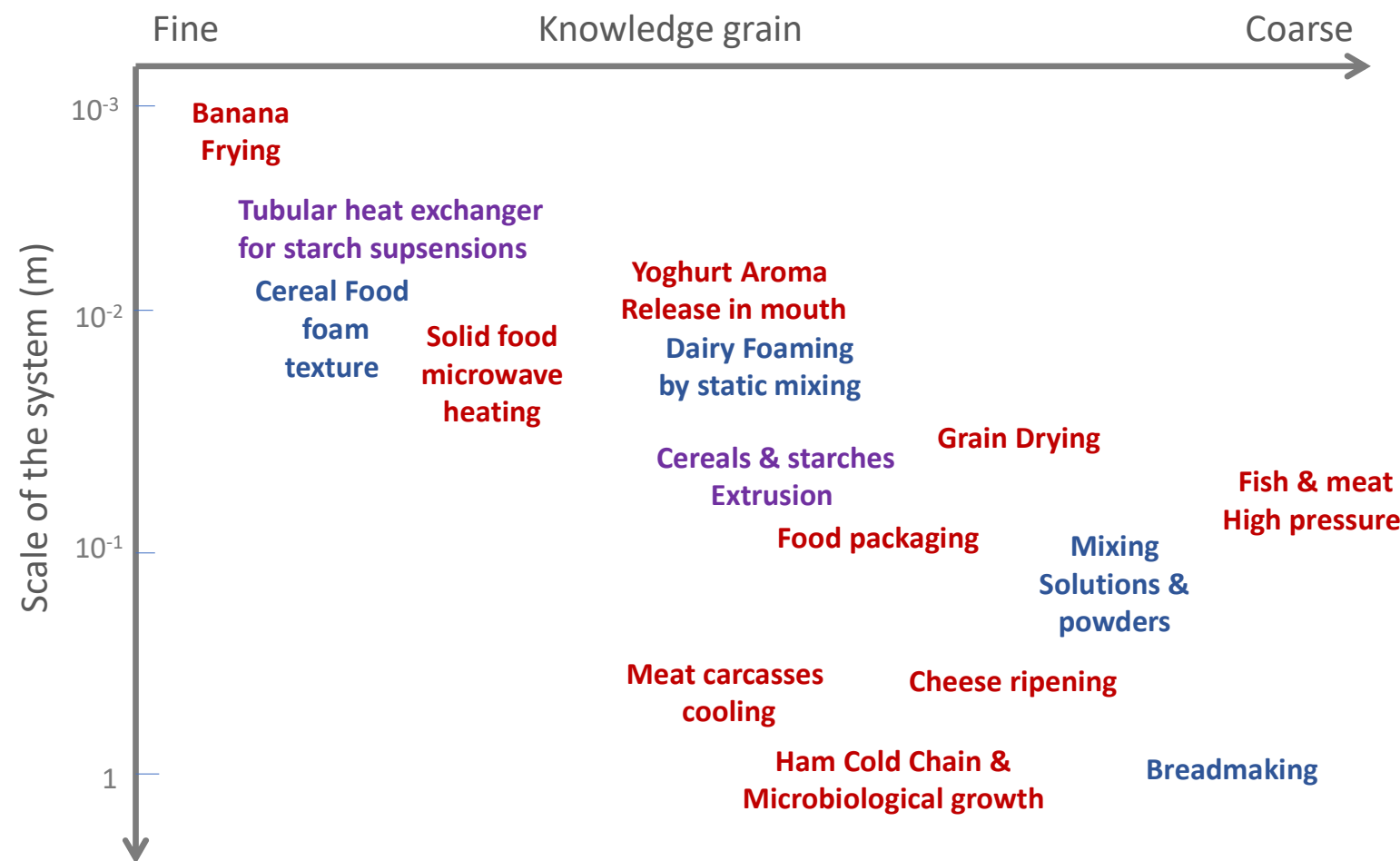

MESTRAL

Fig. 4 
AgreenCamp - MESTRAL : Simulator of Rice grain drying

Air temperature :

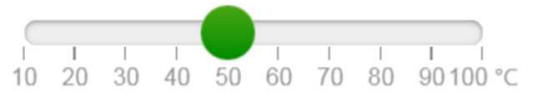

Air relative humidity

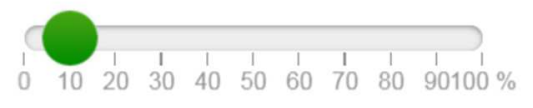

End time :

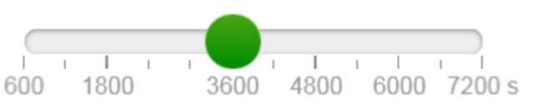

Initial mean entire grain

temperature

Initial head rice yield:

Initial grain water content
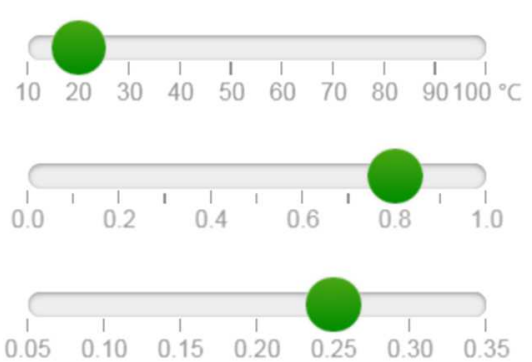

Standard values Automatic setting ${ }^{\triangleright}$ Display results

Inner $\mathbf{X} \mathbf{1}$, average $\mathbf{X}$ and surface $\mathbf{X} \mathbf{2}$ water content

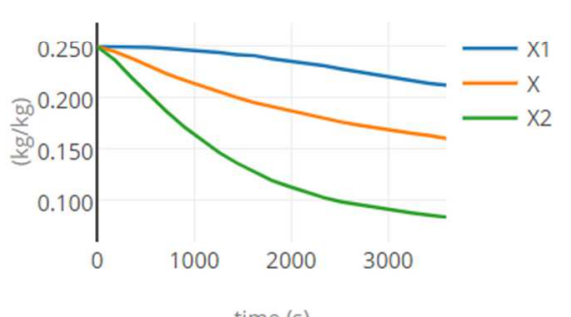

time (s)
Mean entire grain temperature

$\mathrm{Tg}$

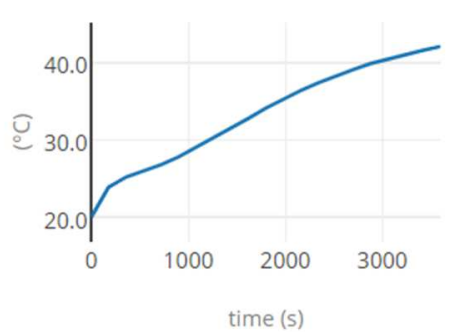

Head rice yield

Q

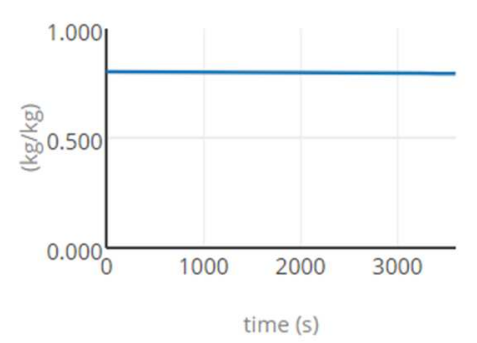

Rice final grain quality

(head rice yield)

$\mathrm{Qf} \approx 0.791$ illustrated by :

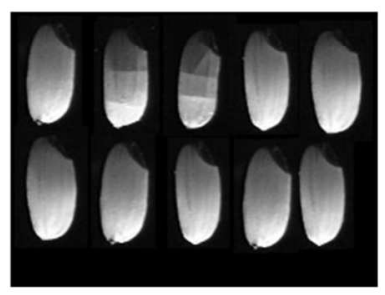

(c)2020, Copyright : INRAE France and AgroParisTech France, licence c(1) (9) 
(b)

AgreenCamp - MESTRAL : Simulator of extrusion-cooking of cereals ans starchy products

Amylose content (\%) :
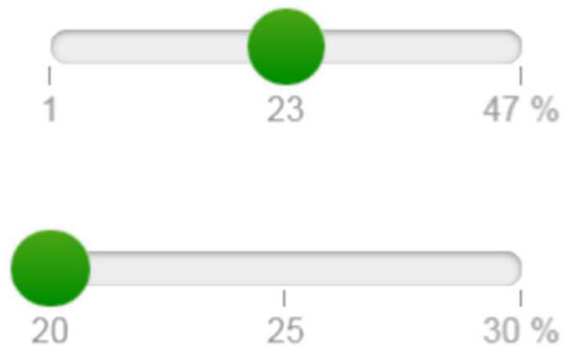

Length of reverse screw element:

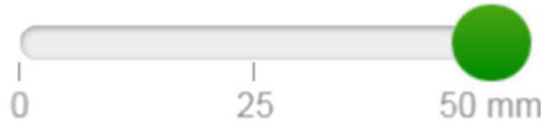

Die diameter :

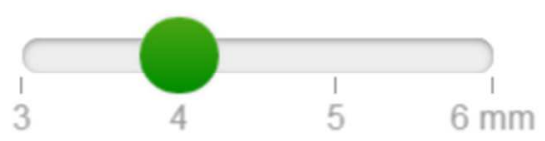

Standard values Automatic setting Display results

T_product

(screw speed, feed rate)
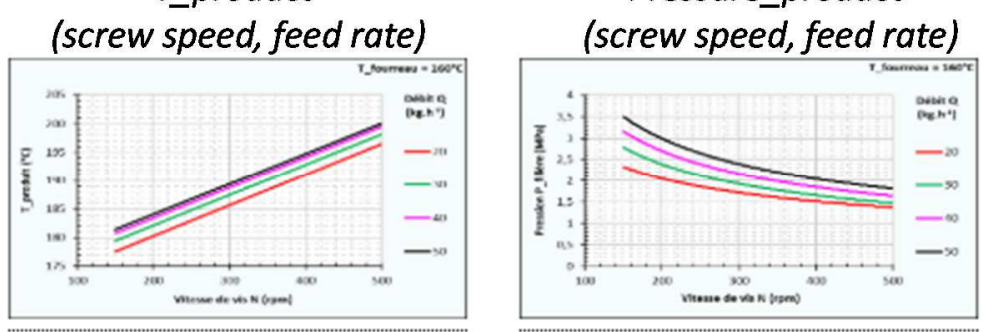

Please click on the graphs to enlarge.

(C)2020, Copyright : INRAE France, licence

\section{(c) (i) ()ㅜㅇㅛ}

Print this page
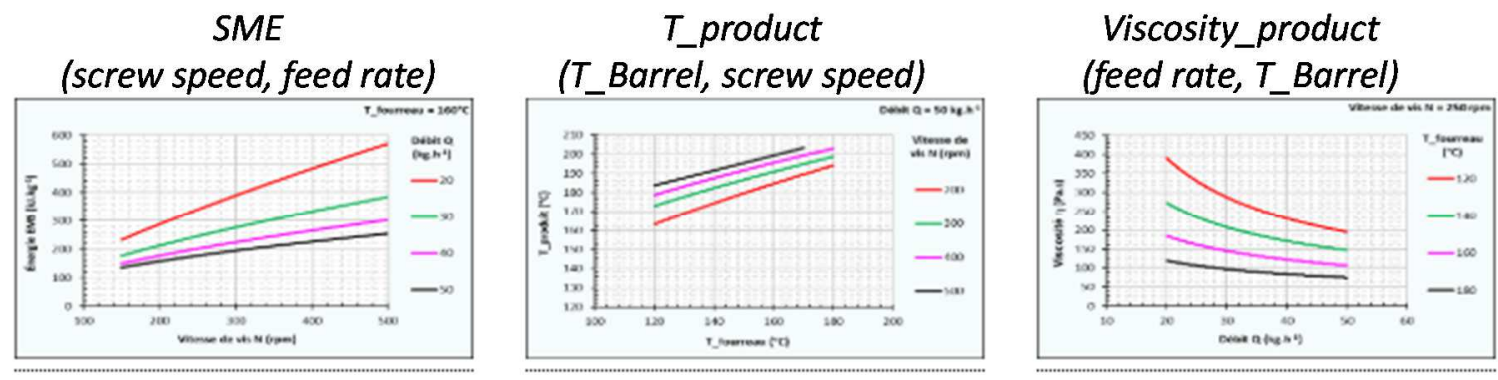

Viscosity_product 
(a)

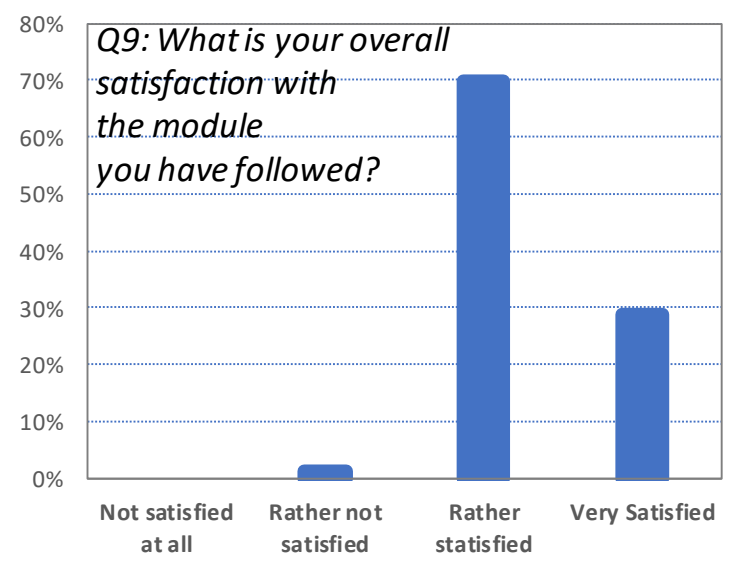

(c)

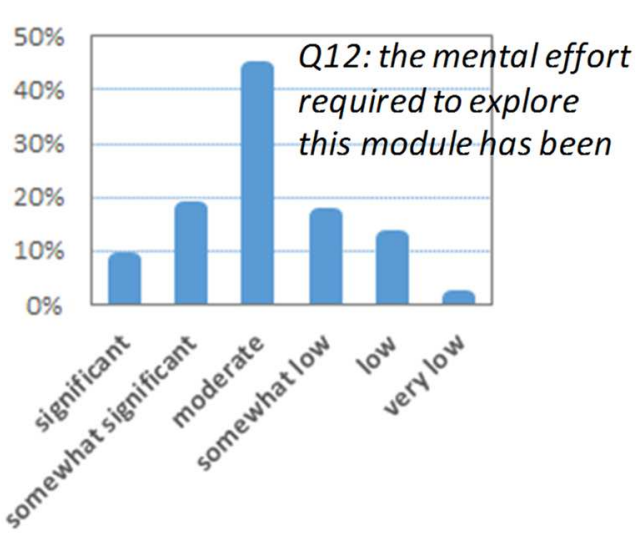

(b)

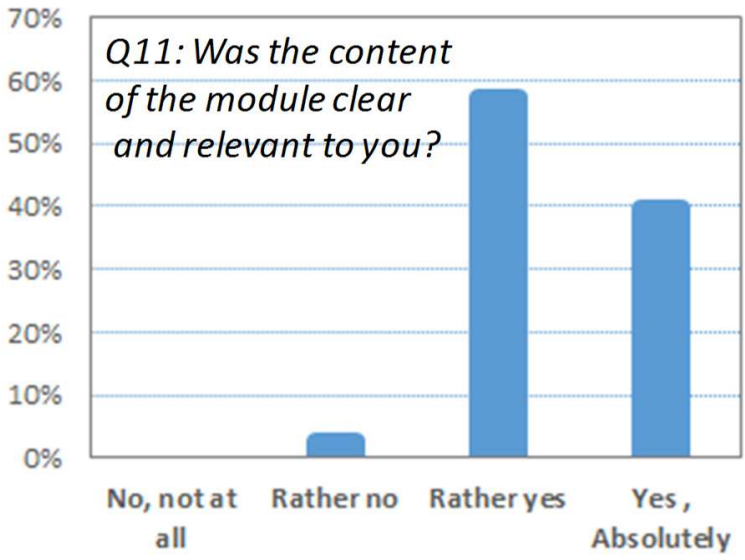

(d)

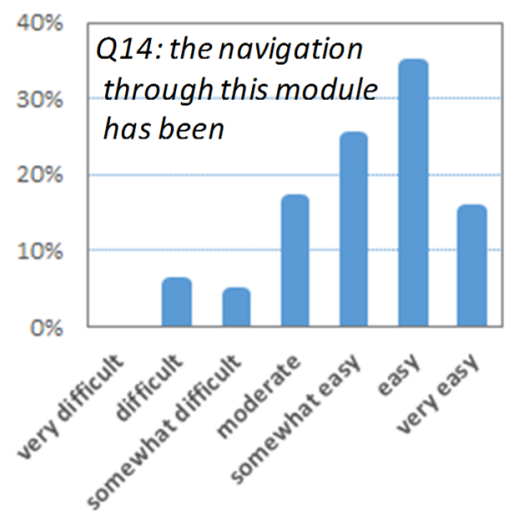

(e)

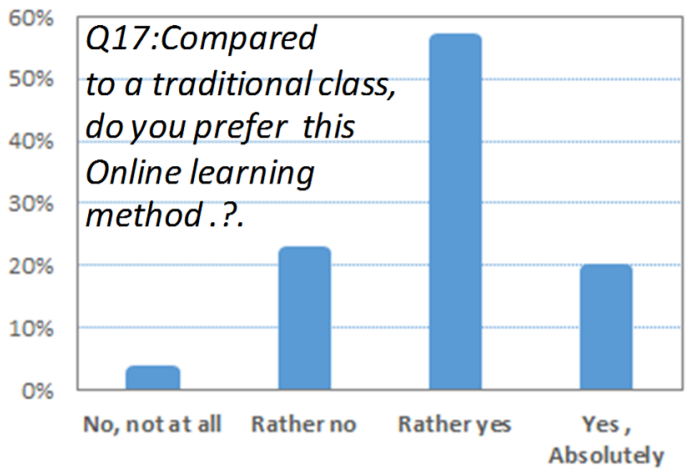

MESTRAL

Fig. 6 . 
Table 1: Overview of the different models represented in MESTRAL and their main characteristics (FEM=Finite Element Method) ordered according to increasing system scale length and coarseness of knowledge grain. " Analytical with compartment » means that differential equations of heat, or mass, or momentum are solved explicitly, (time or space) step by step.

\begin{tabular}{|c|c|c|c|c|c|c|}
\hline $\begin{array}{l}\text { Title } \\
\& \text { Process }\end{array}$ & $\begin{array}{l}\text { Food } \\
\text { system }\end{array}$ & $\begin{array}{l}\text { Theoretical } \\
\text { framework and } \\
\text { model type }\end{array}$ & Inputs $^{a}$ & Outputs $^{a}$ & $\begin{array}{l}\text { Simulator } \\
\text { basis }\end{array}$ & Reference \\
\hline Frying & Banana & 2D-Numerical (FEM) & $\begin{array}{l}\text { Product thermal properties and } \\
\text { geometry, oil properties and } \\
\text { fryer settings }\end{array}$ & $\begin{array}{l}\text { Fields of water, oil contents and } \\
\text { temperature ; composition, } \\
\text { micronutrients and nutrition indices }\end{array}$ & Comsol $^{\mathrm{b}}$ & $\begin{array}{l}\text { Bassama et } \\
\text { al., (2015) }\end{array}$ \\
\hline $\begin{array}{l}\text { Tubular } \\
\text { heat } \\
\text { exchanger }\end{array}$ & $\begin{array}{l}\text { Starch } \\
\text { suspension }\end{array}$ & $\begin{array}{l}\text { 2D- Numerical } \\
\text { (FEM) }\end{array}$ & $\begin{array}{l}\text { Exchanger geometry \& settings, } \\
\text { suspension thermo-rheological } \\
\text { properties and starch swelling } \\
\text { kinetics }\end{array}$ & $\begin{array}{l}\text { Fields of temperature, velocity, } \\
\text { pressure, granule diameter and } \\
\text { volume fraction }\end{array}$ & Comsol $^{b}$ & $\begin{array}{l}\text { Plana-Fattori } \\
\text { et al., (2016) }\end{array}$ \\
\hline $\begin{array}{l}\text { Aroma } \\
\text { release }\end{array}$ & $\begin{array}{l}\text { Yoghurt } \\
\text { in mouth }\end{array}$ & $\begin{array}{l}\text { Numerical with } \\
\text { compartments }\end{array}$ & $\begin{array}{l}\text { Food composition, transfer and } \\
\text { partition coefficients, } \\
\text { consumer's physiology }\end{array}$ & $\begin{array}{l}\text { Time-concentration of aroma } \\
\text { compounds in nose, pharynx and } \\
\text { product }\end{array}$ & MATLAB ${ }^{\circledR}$ & $\begin{array}{l}\text { Trelea et al., } \\
\text { (2008) }\end{array}$ \\
\hline Texture & $\begin{array}{l}\text { Cereal solid } \\
\text { foams }\end{array}$ & 3D Numerical (FEM) & $\begin{array}{l}\text { Food sample geometry, cellular } \\
\text { structure and cell wall's Young } \\
\text { moduli }\end{array}$ & $\begin{array}{l}\text { Local stress \& strain fields, foam } \\
\text { Young modulus }\end{array}$ & Comsol $^{\mathrm{b}}$ & $\begin{array}{l}\text { Guessasma } \\
\text { et al., (2008) }\end{array}$ \\
\hline $\begin{array}{l}\text { Microwave } \\
\text { heating }\end{array}$ & $\begin{array}{l}\text { Pan bread, } \\
\text { beef meat }\end{array}$ & $\begin{array}{l}\text { 1D Numerical (Finite } \\
\text { Volume) }\end{array}$ & $\begin{array}{l}\text { Product physical properties and } \\
\text { thickness, microwave operating } \\
\text { conditions }\end{array}$ & $\begin{array}{l}\text { Time -temperature and microwave } \\
\text { absorbed power at different } \\
\text { locations in food }\end{array}$ & MATLAB $^{\circledR}$ & $\begin{array}{l}\text { Curet et al., } \\
\text { (2009) }\end{array}$ \\
\hline $\begin{array}{l}\text { Static } \\
\text { mixer }\end{array}$ & $\begin{array}{l}\text { Milk liquid } \\
\text { foams }\end{array}$ & $\begin{array}{l}\text { Analytical with } \\
\text { Compartments }\end{array}$ & $\begin{array}{l}\text { Fluid properties, mixer } \\
\text { geometry and settings }\end{array}$ & $\begin{array}{l}\text { Pressure profile, air volume fraction, } \\
\text { mean bubble diameter, foam } \\
\text { viscosity }\end{array}$ & Personal ${ }^{c}$ & $\begin{array}{l}\text { Laporte et } \\
\text { al., (2014) }\end{array}$ \\
\hline $\begin{array}{l}\text { Extrusion } \\
\text { cooking }\end{array}$ & $\begin{array}{l}\text { Cereals \& } \\
\text { starchy } \\
\text { products }\end{array}$ & $\begin{array}{l}\text { Analytical with } \\
\text { Compartments }\end{array}$ & $\begin{array}{l}\text { Material thermo-rheological } \\
\text { properties, extruder geometry } \\
\text { and settings }\end{array}$ & $\begin{array}{l}\text { Material pressure, temperature, } \\
\text { residence time, viscosity and specific } \\
\text { energy profiles }\end{array}$ & Ludovic ${ }^{\circledR}$ & $\begin{array}{l}\text { Della Valle } \\
\text { et al., (1993) }\end{array}$ \\
\hline
\end{tabular}




\begin{tabular}{|c|c|c|c|c|c|c|}
\hline Packaging & $\begin{array}{l}\text { Dry foods, or } \\
\text { fresh } \\
\text { respiring or } \\
\text { not }\end{array}$ & $\begin{array}{l}\text { Analytical with } \\
\text { Compartment and } \\
\text { 1D-numerical }\end{array}$ & $\begin{array}{l}\text { Food \& packaging physical } \\
\text { propertie and geometry, } \\
\text { storage conditions }\end{array}$ & $\begin{array}{l}\text { Head space } \mathrm{CO}_{2}, \mathrm{O}_{2} \text { and micro- } \\
\text { organisms time variations. Packaging } \\
\text { material selection }\end{array}$ & Personal ${ }^{\mathrm{c}}$ & $\begin{array}{l}\text { Guillard et } \\
\text { al., Chaix et } \\
\text { al. (2015) }\end{array}$ \\
\hline Drying & $\begin{array}{l}\text { Corn and rice } \\
\text { grains }\end{array}$ & $\begin{array}{l}\text { Analytical with } \\
\text { Compartment }\end{array}$ & $\begin{array}{l}\text { Inner and surface initial } \\
\text { moisture content, grain physical } \\
\text { properties and dryer settings }\end{array}$ & $\begin{array}{l}\text { Time variations of grain } \\
\text { temperature, moisture content \& } \\
\text { quality }\end{array}$ & Personal $^{c}$ & $\begin{array}{l}\text { Abud Archila } \\
\text { et al., (2000) }\end{array}$ \\
\hline Cooling & $\begin{array}{l}\text { Meat (pork, } \\
\text { rabbit) } \\
\text { carcass }\end{array}$ & 1D - Numerical & $\begin{array}{l}\text { Size, mass \& physical properties } \\
\text { of carcass, conditions of air } \\
\text { velocity, humidity, temperature } \\
\text { \& turbulence }\end{array}$ & $\begin{array}{l}\text { Time -temperature } \& \text { water mass } \\
\text { loss at surface, and inside variations }\end{array}$ & Personal $^{c}$ & $\begin{array}{l}\text { Kondjoyan \& } \\
\text { Daudin, } \\
\text { (1997) }\end{array}$ \\
\hline $\begin{array}{l}\text { High } \\
\text { pressure }\end{array}$ & Fish and meat & Phenomenological & $\begin{array}{l}\text { Initial products characteristics \& } \\
\text { composition, time, pressure \& } \\
\text { temperature settings }\end{array}$ & $\begin{array}{l}\text { Final microbial load, texture and } \\
\text { color }\end{array}$ & Personal $^{c}$ & $\begin{array}{l}\text { Cheret et al., } \\
\text { (2005) }\end{array}$ \\
\hline Agitation & $\begin{array}{l}\text { Syrups and } \\
\text { milk powders }\end{array}$ & $\begin{array}{l}\text { Dimensional } \\
\text { analysis }\end{array}$ & $\begin{array}{l}\text { Geometry, mixer settings, } \\
\text { product properties }\end{array}$ & $\begin{array}{l}\text { Homogeneisation or dissolution } \\
\text { times, consumed power }\end{array}$ & Personal $^{c}$ & $\begin{array}{l}\text { Delaplace et } \\
\text { al., (2015) }\end{array}$ \\
\hline $\begin{array}{l}\text { Bread } \\
\text { making }\end{array}$ & $\begin{array}{l}\text { Wheat flour } \\
\text { dough }\end{array}$ & $\begin{array}{l}\text { Qualitative algebrae } \\
\text { and } \\
\text { phenomenological }\end{array}$ & $\begin{array}{l}\text { Flour composition, mixer } \\
\text { settings, proofing time }\end{array}$ & $\begin{array}{l}\text { Dough rheological properties, } \\
\text { porosity and stability after proofing }\end{array}$ & AsCoPain $^{\circledR}$ & $\begin{array}{l}\text { Ndiaye et } \\
\text { al., (2009) }\end{array}$ \\
\hline Ripening & Cheese & $\begin{array}{l}\text { Dynamic Bayesian } \\
\text { network }\end{array}$ & $\begin{array}{l}\text { Initial pH temperature, } \\
\text { composition, ripening time }\end{array}$ & $\begin{array}{l}\text { Microbial behaviour and evolution of } \\
\text { sensory properties }\end{array}$ & Personal ${ }^{c}$ & $\begin{array}{l}\text { Baudrit et } \\
\text { al., (2010) }\end{array}$ \\
\hline $\begin{array}{l}\text { Cold chain } \\
\text { and micro- } \\
\text { biological } \\
\text { growth }\end{array}$ & Ham & $\begin{array}{l}\text { Analytical with heat } \\
\text { transfer coupled to } \\
\text { previsional } \\
\text { microbiology }\end{array}$ & $\begin{array}{l}\text { probability distributions of } \\
\text { residence time, ambient } \\
\text { temperature, microbial growth }\end{array}$ & $\begin{array}{l}\text { product temperature and microbial } \\
\text { load evolutions }\end{array}$ & Personal $^{c}$ & $\begin{array}{l}\text { Flick et al., } \\
\text { (2012) }\end{array}$ \\
\hline
\end{tabular}

${ }^{a}$ these characteristics are not exhaustive of the model considered but they provide more insight on the system (process, food) modelled.

${ }^{b}$ Comsol stands for COMSOL Multiphysics ${ }^{\circledR}$

${ }^{c}$ " Personal » means that the model has been implemented by the author through current software resources (Office or else) 